OPEN ACCESS

Edited by:

Nicole Gallo-Payet,

University of Sherbrooke, Canada

Reviewed by:

Valerio Magnaghi,

Università Degli Studi di Milano, Italy

Wendy B. Bollag,

Georgia Regents University, USA

*Correspondence:

András Spät

spat@eok.sote.hu

Specialty section:

This article was submitted to Neuroendocrine Science,

a section of the journal

Frontiers in Endocrinology

Received: 12 January 2016 Accepted: 11 February 2016

Published: 29 February 2016

Citation:

Spät A, Hunyady L and Szanda G (2016) Signaling Interactions in the

Adrenal Cortex.

Front. Endocrinol. 7:17. doi: 10.3389/fendo.2016.00017

\section{Signaling Interactions in the Adrenal Cortex}

\author{
András Spät ${ }^{1,2 *}$, László Hunyady ${ }^{1,2}$ and Gergó Szanda ${ }^{1}$ \\ ${ }^{1}$ Department of Physiology, Semmelweis University Medical School, Budapest, Hungary, ${ }^{2}$ Laboratory of Molecular \\ Physiology, Hungarian Academy of Sciences, Budapest, Hungary
}

The major physiological stimuli of aldosterone secretion are angiotensin II (All) and extracellular $\mathrm{K}^{+}$, whereas cortisol production is primarily regulated by corticotropin (ACTH) in fasciculata cells. All triggers $\mathrm{Ca}^{2+}$ release from internal stores that is followed by store-operated and voltage-dependent $\mathrm{Ca}^{2+}$ entry, whereas $\mathrm{K}^{+}$-evoked depolarization activates voltage-dependent $\mathrm{Ca}^{2+}$ channels. ACTH acts primarily through the formation of CAMP and subsequent protein phosphorylation by protein kinase $\mathrm{A}$. Both $\mathrm{Ca}^{2+}$ and CAMP facilitate the transfer of cholesterol to mitochondrial inner membrane. The cytosolic $\mathrm{Ca}^{2+}$ signal is transferred into the mitochondrial matrix and enhances pyridine nucleotide reduction. Increased formation of NADH results in increased ATP production, whereas that of NADPH supports steroid production. In reality, the control of adrenocortical function is a lot more sophisticated with second messengers crosstalking and mutually modifying each other's pathways. Cytosolic $\mathrm{Ca}^{2+}$ and cGMP are both capable of modifying cAMP metabolism, while cAMP may enhance $\mathrm{Ca}^{2+}$ release and voltage-activated $\mathrm{Ca}^{2+}$ channel activity. Besides, mitochondrial $\mathrm{Ca}^{2+}$ signal brings about cAMP formation within the organelle and this further enhances aldosterone production. Maintained aldosterone and cortisol secretion are optimized by the concurrent actions of $\mathrm{Ca}^{2+}$ and cAMP, as exemplified by the apparent synergism of $\mathrm{Ca}^{2+}$ influx (inducing cAMP formation) and $\mathrm{Ca}^{2+}$ release during response to All. Thus, cross-actions of parallel signal transducing pathways are not mere intracellular curiosities but rather substantial phenomena, which fine-tune the biological response. Our review focuses on these functionally relevant interactions between the $\mathrm{Ca}^{2+}$ and the cyclic nucleotide signal transducing pathways hitherto described in the adrenal cortex.

\section{Keywords: cAMP, $\mathrm{Ca}^{2+}$ signal, mitochondria, aldosterone, angiotensin II, ACTH, potassium ion, cortisol}

\section{INTRODUCTION}

The adrenal cortex contains three zones, of which glomerulosa secretes the mineralocorticoid aldosterone, fasciculata synthesizes the glucocorticoid cortisol (or corticosterone in rodents), whereas the reticularis produces androgens [reviewed in Ref. (1)]. Aldosterone, acting on the distal nephron, augments $\mathrm{Na}^{+}$reabsorption as well as $\mathrm{K}^{+}$and $\mathrm{H}^{+}$excretion. Through changes in sodium balance, it influences the extracellular fluid space and blood pressure, and its importance in cardiovascular, renal, and inflammatory diseases has also been recognized (2-4). Cortisol, among other things, controls intermediary metabolism, modulates immune responses, and is essential for the resistance 
of the organism to noxious stimuli. Adrenal androgens exert important anabolic effects in females and have substantial clinical significance in adrenal pathologies.

Sodium and/or fluid depletion, hemodynamic changes, and hyperkalemia stimulate aldosterone secretion. When fluid loss is severe, ACTH synergizes with angiotensin II (AII) in stimulating glomerulosa cells. During hypervolemia, atrial natriuretic peptide (ANP) inhibits aldosterone secretion [for reviews, see Ref. $(5,6)$ ]. Cortisol production is governed by ACTH. The regulation of ACTH secretion and the signaling in zona reticularis (7) are beyond the scope of this review.

\section{CLASSICAL SIGNALING PATHWAYS IN THE ADRENAL CORTEX}

\section{Signaling Pathways in Glomerulosa Cells}

The major signaling pathways of $\mathrm{ACTH}, \mathrm{K}^{+}$, and $\mathrm{AII}$, termed "classical" here have been described in several reviews [e.g., Ref. $(5,6,8,9)]$ and are only briefly summarized below.

ACTH binds to the melanocortin-type receptor MC2R, which activates adenylyl cyclase (AC) via the heterotrimeric G-protein $\mathrm{G}_{\mathrm{s}}(10,11)$, and subsequent cAMP formation activates protein kinase A (PKA). PKA then phosphorylates and induces the hormone-sensitive lipase (previously "cholesterol ester hydrolase") (12) as well as the steroidogenic acute regulatory protein (StAR), the protein transporting cholesterol into the mitochondria (13, 14). As a result of these, the steroid precursor cholesterol is released from lipid droplets and transported to side-chain cleavage by CYP11A1, located in the inner mitochondrial membrane. This causes the stimulation of adrenal steroidogenesis.

Extracellular $\mathrm{K}^{+}$and AII act by generating cytosolic $\mathrm{Ca}^{2+}$ signal. Depolarization induced by physiological elevations of $\left[\mathrm{K}^{+}\right]$ activates T-type voltage-dependent $\mathrm{Ca}^{2+}$ channels the current of which was detected in rat (15-17), bovine $(16,18,19)$, and human glomerulosa cells (20). Concomitant cell swelling evoked by $\mathrm{K}^{+}$ also enhances this T-type current $(21,22)$.

The unique sensitivity of glomerulosa cells to $\mathrm{K}^{+}(6,23,24)$ may be attributed to their high permeability to $\mathrm{K}^{+}(19,25-28)$ and the function of the T-type channel Ca 3 3.2. The channel's subunit $\alpha_{1 \mathrm{H}}$ is expressed in rat, murine, and bovine glomerulosa cell (29, $30)$. In view of the very negative membrane potential of isolated glomerulosa cells $(27,31)$, basal $\mathrm{Ca}^{2+}$ influx was attributed to a steady-state window current $(19,32)$. The control of $\mathrm{Ca}_{\mathrm{v}} 3.2$ in glomerulosa cells has recently been analyzed in murine adrenal slices (30), in which cells had a mean resting potential of $-82 \mathrm{mV}$. Spontaneous membrane potential oscillations generated by $\mathrm{Ca}_{\mathrm{v}} 3.2$ were observed between -87 and $-75 \mathrm{mV}$. Increasing $\left[\mathrm{K}^{+}\right]$ up to $5 \mathrm{mM}$ depolarized the membrane and increased oscillation frequency and peak amplitudes, whereas the increased frequency upon AII stimulation was most probably due to a $\mathrm{G}_{\mathrm{i}}$-mediated shift in the voltage dependence of channel activation toward more negative potentials (33). In either cases, the ensuing $\mathrm{Ca}^{2+}$ signal (via CaMKII and p42/44 MAP kinase) acts on hormonesensitive lipase $(34)$ and StAR $(13,35,36)$ [similarly to the actions of PKA (37)].
Angiotensin II stimulates aldosterone secretion after binding to $\mathrm{AT}_{1}$ receptors (AT1Rs) (38-40). Acting via the G-protein $\mathrm{G}_{\mathrm{q}}$ and phospholipase $\mathrm{C}_{\beta}$, it induces the formation of inositol 1,4,5-trisphosphate $\left(\mathrm{IP}_{3}\right)$ (41-43) which, through specific receptors [IP3Rs (44-46)] generates $\mathrm{Ca}^{2+}$ signal. Out of the three receptor isoforms expressed in glomerulosa cells (47), the dominant $\mathrm{IP}_{3} \mathrm{R} 1$ exhibits the greatest affinity for $\mathrm{IP}_{3}$. The initial $\mathrm{Ca}^{2+}$ release is followed by $\mathrm{Ca}^{2+}$ influx $(48,49)$ through store-operated $(50,51)$ and later via T-type $\mathrm{Ca}^{2+}$ channels $(18,33)$ [but see Ref. (52)]. In isolated rat glomerulosa cells, AII-induced T-type current is activated by depolarization (19) brought about by the inhibition of the $\mathrm{Na}^{+} / \mathrm{K}^{+}$pump (53) and by the two-pore domain $\mathrm{K}^{+}$channel TASK $(25,54)$. In murine cells maintained in situ, $\mathrm{T}$-current is enhanced by a $\mathrm{G}_{\mathrm{i}}$-mediated increase in the frequency of oscillating action potentials $(30,33)$.

Angiotensin II inhibits L-type current (55) and thus attenuates $\mathrm{Ca}^{2+}$ signals evoked by high $\left[\mathrm{K}^{+}\right](56,57)$. This effect of the peptide is mediated by the $\mathrm{G}$-protein $\mathrm{G}_{\mathrm{i}}$, expressed in glomerulosa cells $(55,58)$.

Due to space limits, this review does not deal with diacylglycerol - protein kinase C (PKC), lipoxygenase, and MAPK pathways [reviewed, e.g., in Ref. (6)].

\section{Signaling in Fasciculata Cells}

The physiological stimulus of glucocorticoid synthesis and secretion by fasciculata cells is ACTH, acting via MC2R receptors and cAMP. The mode of cAMP action is identical to that described above for glomerulosa cell [for review, see Ref. (59)].

ACTH action on fasciculata cells requires $\mathrm{Ca}^{2+}$. As observed already in the $70 \mathrm{~s}, \mathrm{ACTH}$ induces membrane potential changes (60) due mainly to $\mathrm{Ca}^{2+}$ influx (61). Both T-type $\left(\mathrm{Ca}_{\mathrm{v}} 3.2\right)$ and L-type ( $\mathrm{Ca}_{\mathrm{v}} 1.3$ and a non-identified) isoforms were characterized in bovine fasciculata cells, and their participation in ACTH- and AII-stimulated cortisol secretion was demonstrated (62). We are not aware of data on $\mathrm{Ca}^{2+}$ channels in rat and native human fasciculata cells; however, the observation that rat fasciculata cells were unresponsive to $13 \mathrm{mM} \mathrm{K}^{+}$(23) indicates the lack of T-type $\mathrm{Ca}^{2+}$ channels. The resting membrane potential in bovine fasciculata cells is set by the background $\mathrm{K}^{+}$channel bTREK-1 (63), whereas the TASK-3 background $\mathrm{K}^{+}$channel, characteristic for rat glomerulosa cell (26), is undetectable in bovine fasciculata cells (64).

Albeit AT1R is expressed in human, bovine, and ovine fasciculata cells (65-67) data whether AII alone stimulates cortisol secretion are conflicting $(62,68-70)$. Rat fasciculata cells do not express detectable amounts of AT1R (71-73) [but see Ref. (74)] or inositol 1,4,5-trisphosphate receptor (IP3R) mRNA (47) and, accordingly, AII does not stimulate steroid production in these cells $(23,74,75)$.

The expression of AT1R in fasciculata cells and the stimulation of cortisol secretion by the peptide raise the question whether AII plays any role in the control of cortisol secretion in man. In lack of comprehensive studies, we hypothesize that in stress situations, stimulation of fasciculata cells by AII may contribute to the stimulatory action of ACTH. On the other hand, in case of long-term high AII levels, cortisol secretion is maintained at resting level by the feed-back control of ACTH secretion. 
The human adrenocortical cancer-derived H295R cell, a widely used model for studying steroid production, does not express either MC2R receptors (76) or $\mathrm{Ca}_{\mathrm{v}} 3.2$ T-type $\mathrm{Ca}^{2+}$ channels (30) [but see Ref. (77)]. Not surprisingly, these cells are insensitive to ACTH and respond to $\mathrm{K}^{+}$at supraphysiological concentrations only (78).

\section{INTERACTION OF SIGNALING PATHWAYS IN ADRENOCORTICAL CELLS}

\section{(Auto)Regulation of $\mathrm{Ca}^{2+}$ Metabolism by $\mathrm{Ca}^{2+}$}

The formation, metabolism, and the action of $\mathrm{IP}_{3}$ all depend on cytosolic $\left[\mathrm{Ca}^{2+}\right]\left(\left[\mathrm{Ca}^{2+}\right]_{c}\right)$. Phospholipase $\mathrm{C}_{\gamma}$, generating $\mathrm{IP}_{3}$ from $\mathrm{PIP}_{2}(79)$ and the $\mathrm{IP}_{3}$ metabolizing $\mathrm{IP}_{3}-3$ kinase are both activated by $\mathrm{Ca}^{2+}(80-82)$. High $\left[\mathrm{Ca}^{2+}\right]_{c}$ may reduce $\mathrm{IP}_{3}$ binding (83), whereas elevation of $\left[\mathrm{Ca}^{2+}\right]_{\mathrm{c}}$ up to $\sim 300 \mathrm{nM}$ increases the sensitivity of $\mathrm{IP}_{3} \mathrm{R} 1$ to $\mathrm{IP}_{3}$ [reviewed in Ref. (6)]. These characteristics play an important role in the oscillatory pattern of $\mathrm{Ca}^{2+}$ release. $\mathrm{IP}_{3} \mathrm{R}$ phosphorylation by $\mathrm{PKA}, \mathrm{PKC}$, or CaMKII enhances $\mathrm{Ca}^{2+}$ release, while calcineurin decreases this phosphorylation state (84). Also, calcium-calmodulin activates the plasmalemmal Ca ATPase (85) and inhibits the $\mathrm{Na}^{+} / \mathrm{K}^{+}$ATPase $(86,87)$, the latter resulting in depolarization and $\mathrm{Ca}^{2+}$ influx through T-type channels (see Signaling Pathways in Glomerulosa Cells).

\section{Effects of $\mathrm{Ca}^{2+}$ on Cytosolic cAMP}

Early reports on $\mathrm{K}^{+}$-evoked cAMP formation suggested a role for $\mathrm{Ca}^{2+}$ in the activation of $\mathrm{AC}(88,89)$. Maintained secretagogue effect of ACTH in rat glomerulosa (90) and bovine fasciculata cells is also $\mathrm{Ca}^{2+}$-dependent (62) with calcium-calmodulin affecting primarily the formation of cAMP (91). In fact, in bovine cells, the effect of ACTH on cAMP formation correlates to extracellular $\left[\mathrm{Ca}^{2+}\right]$ (92), and ACTH-induced cAMP formation is potentiated by AII in the presence of $\mathrm{Ca}^{2+}$ only (69).

Nevertheless, conflicting data were reported concerning the effect of AII on cAMP formation in bovine adrenocortical cells $(69,93-95)$. Reduced cAMP formation was reported in AII-stimulated rat glomerulosa cells $(96,97)$, whereas enhanced cAMP formation was observed in the human H295R cell (98). In this respect, the $\mathrm{Ca}^{2+}$ sensitivity of different transmembrane adenylyl cyclase isoforms $(99,100)$ should be considered. The $\mathrm{Ca}^{2+}$-activatable isoform $\mathrm{AC} 1$ is expressed in human glomerulosa and fasciculata cells (99); the $\mathrm{Ca}^{2+} /$ calmodulin-activatable AC3 was found in human (99), rat (101), and bovine (69) glomerulosa cells. $\mathrm{Ca}^{2+}$-inhibited isoforms (AC5 and AC6) were detected in human (99) and rat glomerulosa cells (102). It should also be kept in mind that $\mathrm{Ca}^{2+}$-activatable $\mathrm{AC}$ isoforms are more responsive to store-operated $\mathrm{Ca}^{2+}$ entry than to $\mathrm{Ca}^{2+}$ release. This phenomenon is due to the colocalization of $\mathrm{Ca}^{2+}$ activatable $\mathrm{AC}$ isoforms and store-operated $\mathrm{Ca}^{2+}$ channels in plasmalemmal lipid rafts (103) and may account for the delayed cAMP response to AII (98).

After the description of $G_{i}$ in rat glomerulosa cells (58), the reported inhibition of AC by AII was attributed to this inhibitory G-protein $(55,95)$. Summarizing, the cell-type differences in the effect AII on AC may be attributed to $G_{i}$ density and the ratio of the various $\mathrm{AC}$ isoforms.

The $\mathrm{Ca}^{2+}$-modified signaling pathways are summarized in Figure 1.

\section{Effects of cAMP on $\mathrm{Ca}^{2+}$ Signaling}

ACTH or cell-permeable cAMP analogs may induce a sustained $\mathrm{Ca}^{2+}$ signal after a lag time of a few minutes as was shown in rat (104), bovine (92), and human glomerulosa cells (105), as well as in H295R cells (106). Several molecular interactions may warrant such an effect. PKA phosphorylates L-type $\mathrm{Ca}^{2+}$ channels $(105,107)$ [but see Ref. (108)], the ensuing $\mathrm{Ca}^{2+}$ current activates phospholipase $\mathrm{C}_{\delta}$, and the generated $\mathrm{IP}_{3}$ induces $\mathrm{Ca}^{2+}$ release from the endoplasmic reticulum (ER). In addition, PKA also phosphorylates and activates $\mathrm{IP}_{3} \mathrm{R} 1$ [reviewed in Ref. (6)]. In fact, ACTH evokes a small phosphoinositide response (109) and PKC activation (110) in rat glomerulosa cells. By the same token, 8Br-cAMP enhanced AII-induced $\mathrm{IP}_{3}$ formation in bovine cells (111). Taken together, cAMP and its downstream effectors may enhance both $\mathrm{Ca}^{2+}$ influx and $\mathrm{Ca}^{2+}$ release in the adrenals.

The cAMP-modified signaling pathways are summarized in Figure 2.

\section{Signaling Modulation by cGMP}

Cyclic GMP is formed after the activation of ANP receptors. The nucleotide reduces T-type $\mathrm{Ca}^{2+}$ current (112) and inhibits the AC (113). In addition, cGMP activates PDE2A (114-116), one of phosphodiesterase isozymes identified in adrenocortical cells [reviewed by Vezzosi and Bertherat (117)]. By these actions, ANP reduces basal and stimulated aldosterone secretion (112).

\section{Synergistic Effects of $\mathrm{Ca}^{2+}$ Release and $\mathrm{Ca}^{2+}$ Influx}

Moderate hyperkalemia increases the sensitivity and the maximal aldosterone response to AII (118-120). Potassium (4-8 mM) potentiates the secretory response to thapsigargin (evoking net $\mathrm{Ca}^{2+}$ release from the ER), whereas the secretory effects of thapsigargin and AII (300 pM) are additive only (119). When net $\mathrm{Ca}^{2+}$ release was induced with $\mathrm{Ni}^{2+}$, an inhibitor of microsomal $\mathrm{Ca}^{2+}$ uptake, the aldosterone response to physiological concentrations of $\mathrm{K}^{+}$was again potentiated (121). These observations indicate that $\mathrm{Ca}^{2+}$ release and influx act in synergism on aldosterone secretion.

The synergism between $\mathrm{Ca}^{2+}$ release and influx maybeexplained by the formation of microdomains. Increased subplasmalemmal $\left[\mathrm{Ca}^{2+}\right]$ (formed around the orifice of $\mathrm{Ca}^{2+}$ channels) may activate e.g., $\mathrm{Ca}^{2+}$-dependent $\mathrm{AC}$ isoforms and may induce specific gene expression $(122,123)$. On the other hand, $\mathrm{Ca}^{2+}$ release into the perinuclear space may turn on $\mathrm{Ca}^{2+}$-dependent nuclear genes and enhance $\mathrm{NAD}(\mathrm{P}) \mathrm{H}$ formation in ER-vicinal mitochondria (see $\mathrm{Ca}^{2+}$ Signal and Mitochondrial Function). In addition, the reduction in exchangeable $\mathrm{Ca}^{2+}$ pool during exposure to AII (124) may be counterbalanced by concomitant $\mathrm{Ca}^{2+}$ influx.

Angiotensin II-induced initial $\mathrm{IP}_{3}$ peak is followed by sustained suprabasal IP3 formation (41). $\mathrm{Li}^{+}$inhibits the resynthesis of phosphoinositides and precludes the maintained formation of $\mathrm{IP}_{3}$, and thus attenuates the post-initial phase of AII-induced 


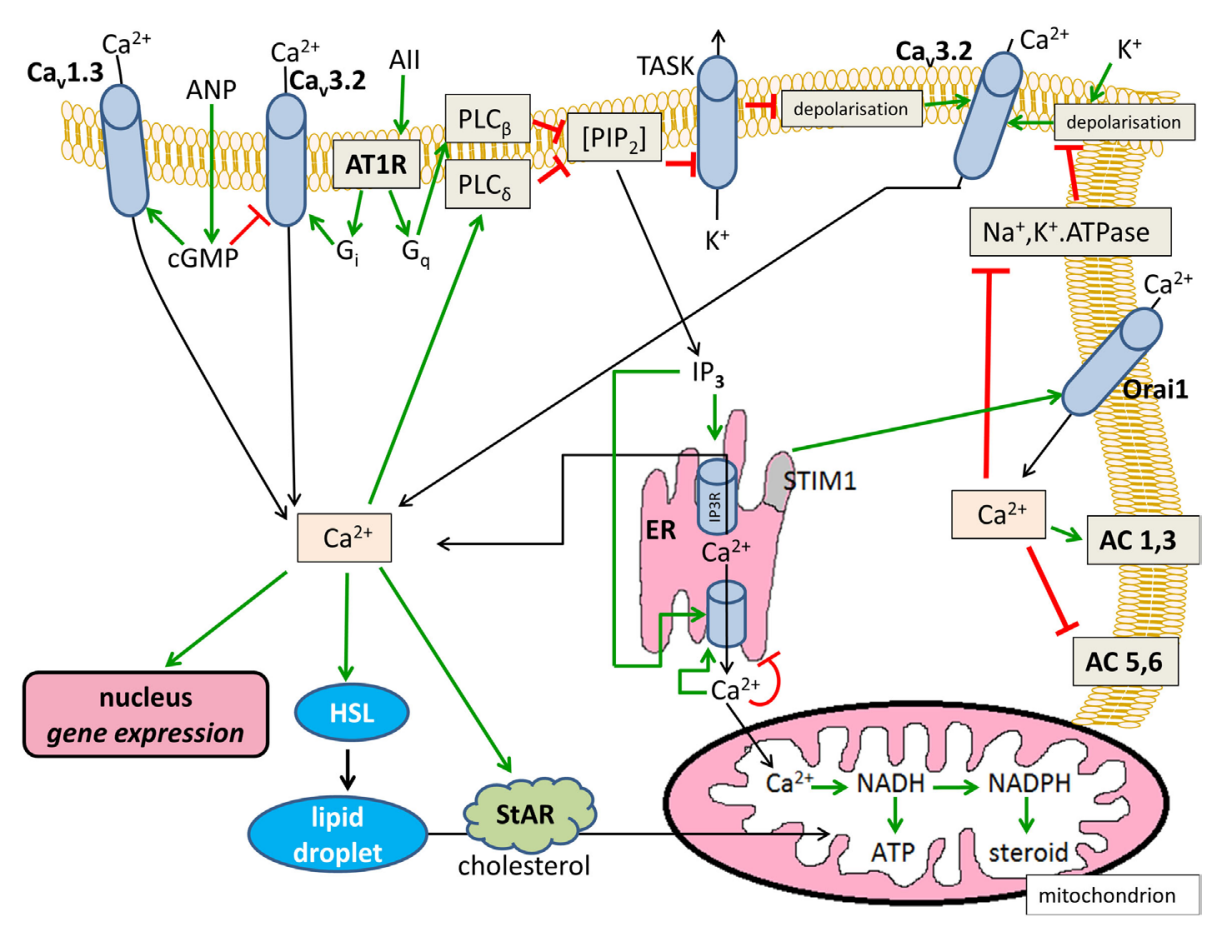

FIGURE 1 | Effects of $\mathbf{C a}^{2+}$ on cytosolic cAMP in glomerulosa cells. Positive modulations are shown with green arrows and negative effects are shown with red blunted arrows. Black arrows indicate substance transport. Cav1.3, L-type voltage-dependent $\mathrm{Ca}^{2+}$ channel; Cav3.2, T-type voltage-dependent Ca ${ }^{2+}$ channel; ANP, atrial natriuretic peptide; All, angiotensin II; AT1R, angiotensin II receptor type 1, $\mathrm{G}_{\mathrm{i}}$ and $\mathrm{G}_{\mathrm{q}}$, heterotrimeric $\mathrm{G}$-proteins; PIP , phosphatidyl inositol 1,4,5-trisphosphate; TASK, KCNK3 or KCNK9-type K+ channel; AC, transmembrane adenylyl cyclase; ER, endoplasmic reticulum; IP, inositol 1,4,5-trisphosphate; IP3R, IP 3 receptor; HSL, hormone-sensitive lipase; StAR, steroidogenic acute regulatory protein.

(but not ACTH-induced) aldosterone output of glomerulosa cells (125). This indicates that sustained suprabasal $\mathrm{IP}_{3}$ formation, $\mathrm{Ca}^{2+}$ release and, probably, store-operated $\mathrm{Ca}^{2+}$ entry all support longlasting aldosterone secretion.

\section{EFFECTS OF CONVERGENT SIGNALING ON GENE EXPRESSION}

Both $\mathrm{Ca}^{2+}$ and cyclic nucleotide signaling affect the transcriptome of adrenocortical cells $(126,127)$. Complex transcriptional or epigenetic (128) changes during adrenal zonation, remodeling, and neoplastic transformation are beyond the scope of this study [for review, see, e.g., Ref. (129, 130)]. Instead, we focus on instances where gene expression is modulated by parallel signal transducing pathways. One illustrative example of such an interplay involves the transcriptional regulation of hormone-sensitive lipase and StAR, both of which are induced by the cAMP-PKA (12-14) and by the $\mathrm{Ca}^{2+}$ pathway $(13,34-36)$. Along similar lines, $\mathrm{Ca}^{2+}$ and cAMP, through overlapping cis regulatory elements, synergistically induce the transcription of aldosterone synthase (CYP11B2) (131) and (as observed in non-adrenal cells) the mitochondrial $\mathrm{Ca}^{2+}$ uniporter (MCU, see below) (132). Transcription of type I $3 \beta$-hydroxysteroid dehydrogenase (HSD3B1), expressed predominantly in the human zona glomerulosa (133), can be induced by AII but not by $\mathrm{K}^{+}$(134). A plausible explanation is that only AII [in part via PKC (135,
136)] recruits the nuclear receptor subfamily 4 (NGFI-B), which is also necessary for the induction of HSD3B1. In contrast, both AII and $\mathrm{K}^{+}$induce CYP11B2 expression via the $\mathrm{Ca}^{2+} / \mathrm{CaMK}$ and MAP kinase pathways (137).

In vascular smooth muscle cells, both $\mathrm{G}_{\mathrm{s}^{-}}$and $\mathrm{G}_{\mathrm{q}^{-}}$-initiated signaling dampen the expression of AT1R through mRNA destabilization (138). Interestingly, to carry out this mRNA degradation, the pathways partially converge on PKA (139). An effect closely reminiscent of such a convergence was observed in H295R cells where forskolin, db-cAMP, and AII all brought about a rapid drop in AT1R message levels. [Nevertheless, long-term AT1R repression was induced with forskolin/db-cAMP only (140).]

\section{$\mathrm{Ca}^{2+}$ SIGNAL AND MITOCHONDRIAL FUNCTION}

Calcium activates three dehydrogenases in suspended or homogenized mitochondria (141). $\mathrm{Ca}^{2+}$-dependent mitochondrial $\mathrm{NADH}$ and $\mathrm{NADPH}(\mathrm{NAD}(\mathrm{P}) \mathrm{H})$ formation in living cells was first demonstrated in $\mathrm{K}^{+}$-stimulated glomerulosa cells (142). Similar response to AII and vasopressin was also reported (143, 144). The significance of increased NADH and ensuing ATP production (145) in any biological response is obvious, whereas NADPH is a cofactor of steroid biosynthesis (1). Noteworthy, the spatial and temporal pattern of AII-induced cytosolic $\mathrm{Ca}^{2+}$ signal depends on mitochondrial metabolism (78). 


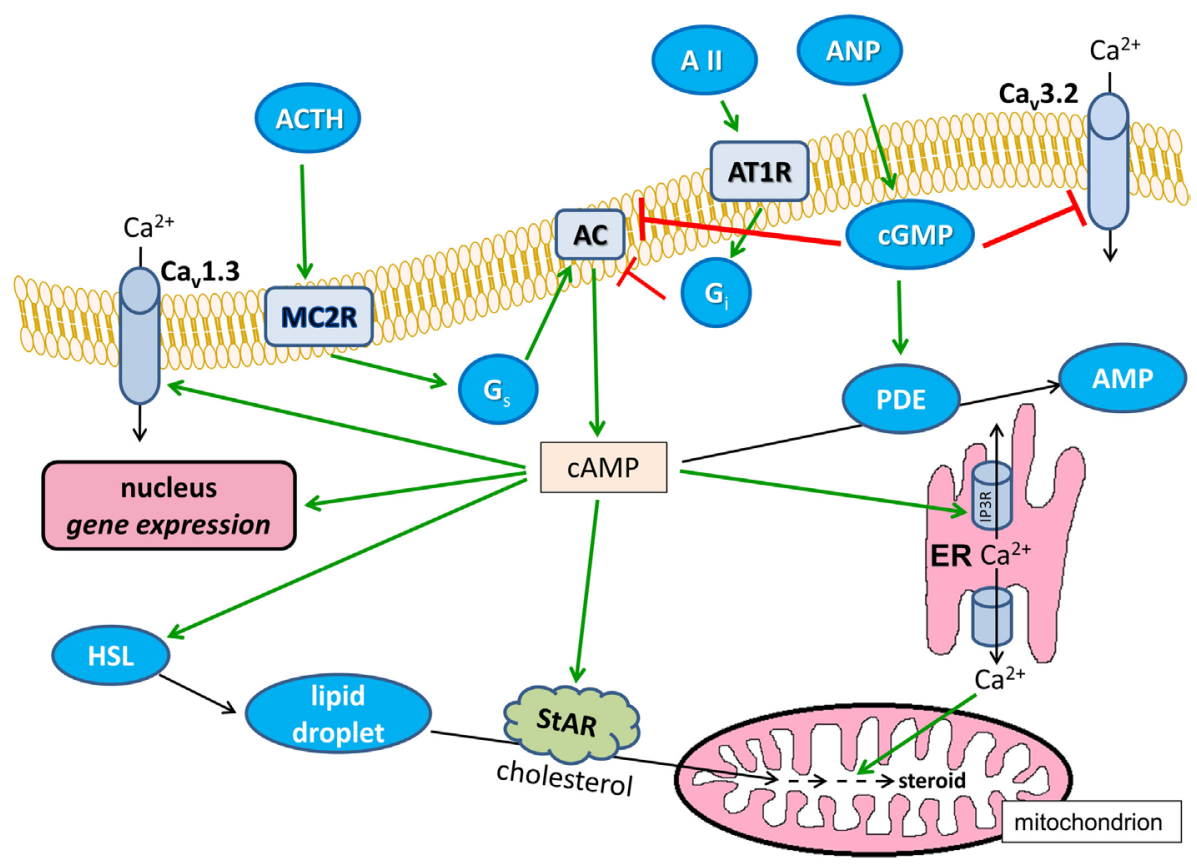

FIGURE 2 | Effects of cAMP on $\mathbf{C a}^{2+}$ signaling in glomerulosa cells. Positive modulations are shown with green arrows and negative effects are shown with red blunted arrows. Black arrows indicate substance transport. Ca 1.3 , L-type voltage-dependent $\mathrm{Ca}^{2+}$ channel; Cav3.2, T-type voltage-dependent Ca ${ }^{2+}$ channel; ANP, atrial natriuretic peptide; All, angiotensin II; AT1R, angiotensin II receptor type 1, $\mathrm{G}_{\mathrm{i}}$ and $\mathrm{G}_{\mathrm{q}}$, heterotrimeric G-proteins; AC, transmembrane adenylyl cyclase; ER, endoplasmic reticulum; IP3R, IP 3 receptor; HSL, hormone-sensitive lipase; StAR, steroidogenic acute regulatory protein; ACTH, corticotropin; MC2R, melanocortin receptor type 2, PDE, cAMP phosphodiesterase; AMP, adenosine monophosphate.

The primary event in the mitochondrial response to a cytosolic $\mathrm{Ca}^{2+}$ signal is the transfer of the ion into the mitochondrial matrix (146-149). $\mathrm{Ca}^{2+}$ transport occurs through the MCU complex, the velocity of which is a sigmoid function of $\left[\mathrm{Ca}^{2+}\right]_{c}$ due to the allosteric control of the MCU channel by the regulatory subunits MICU1 and MICU2 [reviewed in Ref. (150)]. IP ${ }_{3}$-induced $\mathrm{Ca}^{2+}$ release from the ER generates high- $\mathrm{Ca}^{2+}$ microdomains between the ER and mitochondria and allows for mitochondrial $\mathrm{Ca}^{2+}$ uptake by the low-Ca ${ }^{2+}$-affinity MCU (151). However, the mitochondria of glomerulosa cells are uniquely sensitive to $\mathrm{Ca}^{2+}$ (152) and influx-induced low- $\mathrm{Ca}^{2+}$ signals are also effective in elevating mitochondrial $\left[\mathrm{Ca}^{2+}\right]\left(\left[\mathrm{Ca}^{2+}\right]_{\mathrm{m}}\right)(153)$. This responsiveness may be essential for maintained aldosterone secretion in response to long-lasting hyperkalemia, characterized by small elevation of $\left[\mathrm{Ca}^{2+}\right]_{c}$.

Increased $\left[\mathrm{Ca}^{2+}\right]_{\mathrm{m}}$ and the ensuing $\mathrm{NAD}(\mathrm{P}) \mathrm{H}$ formation play an essential role in the stimulation of aldosterone production. Targeted mitochondrial expression of a $\mathrm{Ca}^{2+}$ binding protein reduces both $\left[\mathrm{Ca}^{2+}\right]_{\mathrm{m}}$ and $\mathrm{NAD}(\mathrm{P}) \mathrm{H}$ and ensuing aldosterone production in response to AII (154). The opposite, increased mitochondrial $\mathrm{Ca}^{2+}$ uptake after the knockdown of p38 MAPK or the silencing of mitochondrial protein OPA1 results in increased $\mathrm{NAD}(\mathrm{P}) \mathrm{H}$ formation and enhanced aldosterone production (155).

A recently recognized and biologically significant action of $\mathrm{Ca}^{2+}$ signaling is the formation of cAMP in mitochondria. In addition to the nine isoforms of transmembrane AC, a soluble isoform (sAC) was prepared from testis (156). Its activity is not influenced by forskolin or G-proteins but increased by bicarbonate (157) and $\mathrm{Ca}^{2+}$ (158). The expression of sAC in the mitochondrial matrix together with a degrading mechanism sensitive to phosphodiesterase $2 \mathrm{~A}$ inhibitors were recently described in HeLa cells $(159,160)$. The activity of intramitochondrial sAC increased in response to mitochondrial $\mathrm{Ca}^{2+}$ signal in $\mathrm{HeLa}$ and $\mathrm{CHO}$ cells and in rat cardiomyocytes (161). Importantly, mitochondrial cAMP (mt-cAMP) supported ATP formation (160, 161).

The sAC is also expressed in H295R adrenocortical cells, and it is found in the particulate fraction predominantly. In these cells, AII-induced mitochondrial $\mathrm{Ca}^{2+}$ signal increased the formation of mt-cAMP, and this response was enhanced by the PDE2A inhibitor EHNA. Mitochondrial cAMP signaling was attenuated with the sAC inhibitor 2-OH-estradiol, after silencing of the sAC gene and by the buffering of mitochondrial $\mathrm{Ca}^{2+}$ by S100G protein. All these maneuvers also attenuated aldosterone production, showing the cell-type-specific significance of mt-cAMP for the first time (98).

\section{CONCLUSION}

Adrenocortical steroid production is under the control of both $\mathrm{Ca}^{2+}$ signaling and cyclic nucleotide metabolism. Importantly, these intracellular pathways are rarely, or probably never, independent. As postulated by Berridge in 1975 (162), cAMP and $\mathrm{Ca}^{2+}$ signaling may be antagonistic or synergistic in nature 
and, as hopefully accentuated by this review, the adrenal cortex is no exception to this rule. As shown in Figures $\mathbf{1}$ and 2, the aforementioned signal transducing pathways have the potential to interact at a number of points and levels of signaling. However, it needs to be stressed that these potential interactions are not enforced all at once but, instead, may be limited temporally and spatially (e.g., to signaling microdomains). Also, significant variance in the expression pattern and intensity of the relevant signaling molecules is to be expected depending on species and on the stimuli the organism is concurrently exposed to.

In spite of the interspecies differences and of the incongruences in some experimental data, it is probably safe to conclude that an adequate biological response necessitates the intricate interplay of parallel signaling pathways. That is to say that, e.g., in glomerulosa cells, sustained aldosterone response evoked by long-lasting tonic stimuli will be satisfactory only if the $\mathrm{Ca}^{2+}$ release/influx is accompanied by the sufficient formation of cAMP. Albeit the secretagogues AII and $\mathrm{K}^{+}$invoke predominantly $\mathrm{Ca}^{2+}$ signaling

\section{REFERENCES}

1. Vinson GP, Whitehouse B, Hinson J. The Adrenal Cortex. Englewood Cliffs, NJ: Prentice Hall (1992). p. 65-139.

2. Gomez-Sanchez CE. Non renal effects of aldosterone. Steroids (2014) 91:1-2. doi:10.1016/j.steroids.2014.10.003

3. Pacurari M, Kafoury R, Tchounwou PB, Ndebele K. The Renin-Angiotensinaldosterone system in vascular inflammation and remodeling. Int J Inflam (2014) 2014:689360. doi:10.1155/2014/689360

4. Auchus RJ. Classics in cardiovascular endocrinology - aldosterone action beyond electrolytes. Endocrinology (2016) 157(2):429-31. doi:10.1210/ en.2015-2061

5. Bollag WB. Regulation of aldosterone synthesis and secretion. Compr Physiol (2014) 4:1017-55. doi:10.1002/cphy.c130037

6. Spät A, Hunyady L. Control of aldosterone secretion: a model for convergence in cellular signaling pathways. Physiol Rev (2004) 84:489-539. doi:10.1152/ physrev.00030.2003

7. Parker LN. Control of adrenal androgen secretion. Endocrinol Metab Clin North Am (1991) 20(2):401-21.

8. Hattangady NG, Olala LO, Bollag WB, Rainey WE. Acute and chronic regulation of aldosterone production. Mol Cell Endocrinol (2012) 350:151-62. doi:10.1016/j.mce.2011.07.034

9. Payne AH, Hales DB. Overview of steroidogenic enzymes in the pathway from cholesterol to active steroid hormones. Endocr Rev (2004) 25:947-70. doi:10.1210/er.2003-0030

10. Albano JDM, Brown BL, Ekins RP, Tait SAS, Tait JF. The effects of potassium, 5-hydroxytryptamine, adrenocorticotropin and angiotensin II on the concentration of adenosine $3^{\prime}: 5^{\prime}$-cyclic monophosphate in suspensions of dispersed rat adrenal zona glomerulosa and zona fasciculata cells. Biochem J (1974) 142:391-400. doi:10.1042/bj1420391

11. Grahame-Smith DG, Butcher RW, Ney RL, Sutherland EW. Adenosine 3'5'-monophosphate as the intracellular mediator of the action of adrenocorticotropic hormone on the adrenal cortex. J Biol Chem (1967) 242:5535-41.

12. Holm C, Osterlund T, Laurell H, Contreras JA. Molecular mechanisms regulating hormone-sensitive lipase and lipolysis. Annu Rev Nutr (2000) 20:365-93. doi:10.1146/annurev.nutr.20.1.365

13. Kim YC, Ariyoshi N, Artemenko I, Elliott ME, Bhattacharyya KK, Jefcoate CR. Control of cholesterol access to cytochrome P450scc in rat adrenal cells mediated by regulation of the steroidogenic acute regulatory protein. Steroids (1997) 62:10-20. doi:10.1016/S0039-128X(96)00153-5

14. Rone MB, Fan J, Papadopoulos V. Cholesterol transport in steroid biosynthesis: role of protein-protein interactions and implications in disease states. Biochim Biophys Acta (2009) 179:646-58. doi:10.1016/j. bbalip.2009.03.001 and the effects of ACTH are mediated chiefly by cAMP, the increase of both factors at the same time may potentiate the final response. Thus, the separate intracellular pathways need not be activated to the same extent but nevertheless have to be recruited simultaneously for a sufficient steroid production to follow.

\section{AUTHOR CONTRIBUTIONS}

AS and GS compiled the literary data and wrote the manuscript. Data on the control of expression have been discussed with LH.

\section{ACKNOWLEDGMENTS}

The authors were supported by the Hungarian Academy of Sciences and by the Hungarian National Science Foundation (OTKA NK100883). GS was also supported by the János Bolyai Research Scholarship of the Hungarian Academy of Sciences. The artwork of the figures was kindly prepared by Ms. Anna Szilágyi.

15. Durroux T, Gallo-Payet N, Payet MD. Three components of the calcium current in cultured glomerulosa cells from rat adrenal gland. J Physiol (1988) 404:713-29. doi:10.1113/jphysiol.1988.sp017315

16. Quinn SJ, Brauneis U, Tillotson DL, Cornwall MC, Williams GH. Calcium channels and control of cytosolic calcium in rat and bovine zona glomerulosa cells. Am J Physiol (1992) 262:C598-606.

17. Várnai P, Osipenko ON, Vizi ES, Spät A. Activation of calcium current in voltage-clamped rat glomerulosa cells by potassium ions. J Physiol (1995) 483:67-78. doi:10.1113/jphysiol.1995.sp020568

18. Cohen CJ, McCarthy RT, Barrett PQ, Rasmussen H. Ca channels in adrenal glomerulosa cells: $\mathrm{K}^{+}$and angiotensin II increase T-type Ca channel current. Proc Natl Acad Sci U S A (1988) 85:2412-6. doi:10.1073/pnas.85.7.2412

19. Lotshaw DP. Role of membrane depolarization and T-type $\mathrm{Ca}^{2+}$ channels in angiotensin II and $\mathrm{K}^{+}$stimulated aldosterone secretion. Mol Cell Endocrinol (2001) 175:157-71. doi:10.1016/S0303-7207(01)00384-7

20. Payet MD, Durroux T, Bilodeau L, Guillon G, Gallo-Payet N. Characterization of $\mathrm{K}^{+}$and $\mathrm{Ca}^{2+}$ ionic currents in glomerulosa cells from human adrenal glands. Endocrinology (1994) 134:2589-98. doi:10.1210/endo.134.6.7515004

21. Makara JK, Petheo GL, Tóth A, Spät A. Effect of osmolarity on aldosterone production by rat adrenal glomerulosa cells. Endocrinology (2000) 141:1705-10. doi:10.1210/endo.141.5.7465

22. Makara JK, Koncz P, Petheo GL, Spät A. Role of cell volume in $\mathrm{K}^{+}$-induced $\mathrm{Ca}^{2+}$ signaling by rat adrenal glomerulosa cells. Endocrinology (2003) 144:4916-22. doi:10.1210/en.2003-0383

23. Braley LM, Williams GH. Rat adrenal cell sensitivity to angiotensin II, alpha-1-24-ACTH, and potassium: a comparative study. Am J Physiol (1977) 233:E402-6.

24. Spät A. Glomerulosa cell-a unique sensor of extracellular $\mathrm{K}^{+}$concentration. Mol Cell Endocrinol (2004) 217:23-6. doi:10.1016/j.mce.2003.10.046

25. Czirják G, Fischer T, Spät A, Lesage F, Enyedi P. TASK (TWIK-related acid-sensitive $\mathrm{K}^{+}$channel) is expressed in glomerulosa cells of rat adrenal cortex and inhibited by angiotensin II. Mol Endocrinol (2000) 14:863-74. doi:10.1210/mend.14.6.0466

26. Czirják G, Enyedi P. TASK-3 dominates the background potassium conductance in rat adrenal glomerulosa cells. Mol Endocrinol (2002) 16:621-9. doi:10.1210/me.16.3.621

27. Quinn SJ, Cornwall MC, Williams GH. Electrical properties of isolated rat adrenal glomerulosa and fasciculata cells. Endocrinology (1987) 120:903-14. doi:10.1210/endo-120-3-903

28. Velarde-Miranda C, Gomez-Sanchez EP, Gomez-Sanchez CE. Regulation of aldosterone biosynthesis by the Kir3.4 (KCNJ5) potassium channel. Clin Exp Pharmacol Physiol (2013) 40(12):895-901. doi:10.1111/1440-1681.12151

29. Schrier AD, Wang H, Talley EM, Perez-Reyes E, Barrett PQ. alpha1H T-type $\mathrm{Ca}^{2+}$ channel is the predominant subtype expressed in bovine and rat zona glomerulosa. Am J Physiol Cell Physiol (2001) 280:C265-72. 
30. Hu C, Rusin CG, Tan Z, Guagliardo NA, Barrett PQ. Zona glomerulosa cells of the mouse adrenal cortex are intrinsic electrical oscillators. J Clin Invest (2012) 122(6):2046-53. doi:10.1172/JCI61996

31. Várnai P, Petheö GL, Makara JK, Spät A. Electrophysiological study on the high K $\mathrm{K}^{+}$sensitivity of rat glomerulosa cells. Pflügers Arch (1998) 435:429-31. doi:10.1007/s004240050534

32. Barrett PQ, Ertel EA, Smith MM, Nee JJ, Cohen CJ. Voltage-gated calcium currents have two opposing effects on the secretion of aldosterone. Am J Physiol Cell Physiol (1995) 268:C985-92.

33. Lu HK, Fern RJ, Luthin D, Linden J, Liu LP, Cohen CJ, et al. Angiotensin II stimulates T-type $\mathrm{Ca}^{2+}$ channel currents via activation of a $\mathrm{G}$ protein, $\mathrm{G}_{\mathrm{i}}$. Am J Physiol Cell Physiol (1996) 271:C1340-9.

34. Cherradi N, Pardo B, Greenberg AS, Kraemer FB, Capponi AM. Angiotensin II activates cholesterol ester hydrolase in bovine adrenal glomerulosa cells through phosphorylation mediated by $\mathrm{p} 42 / \mathrm{p} 44$ mitogen-activated protein kinase. Endocrinology (2003) 144:4905-15. doi:10.1210/en.2003-0325

35. Cherradi N, Brandenburger Y, Capponi AM. Mitochondrial regulation of mineralocorticoid biosynthesis by calcium and the StAR protein. Eur J Endocrinol (1998) 139:249-56. doi:10.1530/eje.0.1390249

36. Clark BJ, Combs R. Angiotensin II and cyclic adenosine 3',5'-monophosphate induce human steroidogenic acute regulatory protein transcription through a common steroidogenic factor-1 element. Endocrinology (1999) 140:4390-8. doi:10.1210/en.140.10.4390

37. Capponi AM. The control by angiotensin II of cholesterol supply for aldosterone biosynthesis. Mol Cell Endocrinol (2004) 217:113-8. doi:10.1016/j. mce.2003.10.055

38. Whitebread S, Mele M, Kamber B, De Gasparo M. Preliminary biochemical characterization of two angiotensin II receptor subtypes. Biochem Biophys Res Commun (1989) 163:284-91. doi:10.1016/0006-291X(89)92133-5

39. Balla T, Baukal AJ, Eng S, Catt KJ. Angiotensin II receptor subtypes and biological responses in the adrenal cortex and medulla. Mol Pharmacol (1991) 40:401-6.

40. Hajnóczky G, Csordás G, Bagó A, Chiu AT, Spät A. Angiotensin II exerts its effect on aldosterone production and potassium permeability through receptor subtype $\mathrm{AT}_{1}$ in rat adrenal glomerulosa cells. Biochem Pharmacol (1992) 43:1009-12. doi:10.1016/0006-2952(92)90606-J

41. Enyedi P, Büki B, Mucsi I, Spät A. Polyphosphoinositide metabolism in adrenal glomerulosa cells. Mol Cell Endocrinol (1985) 41:105-12. doi:10.1016/0303-7207(85)90147-9

42. Rossier MF, Capponi AM, Vallotton MB. Inositol trisphosphate isomers in angiotensin II-stimulated adrenal glomerulosa cells. Mol Cell Endocrinol (1988) 57:163-8. doi:10.1016/0303-7207(88)90071-8

43. Baukal AJ, Balla T, Hunyady L, Hausdorff W, Guillemette G, Catt $\mathrm{KJ}$. Angiotensin II and guanine nucleotides stimulate formation of inositol 1,4,5-trisphosphate and its metabolites in permeabilized adrenal glomerulosa cells. J Biol Chem (1988) 263:6087-92.

44. Baukal AJ, Guillemette G, Rubin R, Spät A, Catt KJ. Binding sites for inositol trisphosphate in the bovine adrenal cortex. Biochem Biophys Res Commun (1985) 133:532-8. doi:10.1016/0006-291X(85)90939-8

45. Guillemette G, Balla T, Baukal AJ, Spät A, Catt KJ. Intracellular receptors for inositol 1,4,5-trisphosphate in angiotensin II target tissues. J Biol Chem (1987) 262:1010-5.

46. Spät A, Bradford PG, McKinney JS, Rubin RP, Putney JW Jr. A saturable receptor for ${ }^{32} \mathrm{P}$-inositol-1,4,5-triphosphate in hepatocytes and neutrophils. Nature (1986) 319:514-6. doi:10.1038/319514a0

47. Enyedi P, Szabadkai G, Horváth A, Szilágyi L, Gráf L, Spät A. Inositol 1,4,5-trisphosphate receptor subtypes in adrenal glomerulosa cells. Endocrinology (1994) 134:2354-9. doi:10.1210/en.134.6.2354

48. Hunyady L, Rohács T, Bagó A, Deák F, Spät A. Dihydropyridine-sensitive initial component of the ANG II-induced $\mathrm{Ca}^{2+}$ response in rat adrenal glomerulosa cells. Am J Physiol Cell Physiol (1994) 266:C67-72.

49. Kramer RE. Angiotensin II-stimulated changes in calcium metabolism in cultured glomerulosa cells. Mol Cell Endocrinol (1988) 60:199-210. doi:10.1016/0303-7207(88)90179-7

50. Burnay MM, Python CP, Vallotton MB, Capponi AM, Rossier MF. Role of the capacitative calcium influx in the activation of steroidogenesis by angiotensin-II in adrenal glomerulosa cells. Endocrinology (1994) 135:751-8. doi:10.1210/en.135.2.751
51. Rohács T, Bagó A, Deák F, Hunyady L, Spät A. Capacitative $\mathrm{Ca}^{2+}$ influx in adrenal glomerulosa cells. Possible role in angiotensin II response. Am J Physiol (1994) 267:C1246-52.

52. Rossier MF, Aptel HBC, Python CP, Burnay MM, Vallotton MB, Capponi AM. Inhibition of low threshold calcium channels by angiotensin II in adrenal glomerulosa cells through activation of protein kinase. J Biol Chem (1995) 270:15137-42. doi:10.1074/jbc.270.25.15137

53. Hajnóczky G, Csordás G, Hunyady L, Kalapos MP, Balla T, Enyedi P, et al. Angiotensin-II inhibits $\mathrm{Na}^{+} / \mathrm{K}^{+}$pump in rat adrenal glomerulosa cells: possible contribution to stimulation of aldosterone production. Endocrinology (1992) 130:1637-44. doi:10.1210/endo.130.3.1311245

54. Lopes CM, Rohacs T, Czirjak G, Balla T, Enyedi P, Logothetis DE. PIP2 hydrolysis underlies agonist-induced inhibition and regulates voltage gating of two-pore domain $\mathrm{K}^{+}$channels. J Physiol (2005) 564:117-29. doi:10.1113/ jphysiol.2004.081935

55. Maturana AD, Casal AJ, Demaurex N, Vallotton MB, Capponi AM, Rossier MF. Angiotensin II negatively modulates L-type calcium channels through a pertussis toxin-sensitive G protein in adrenal glomerulosa cells. J Biol Chem (1999) 274:19943-8. doi:10.1074/jbc.274.28.19943

56. Balla T, Holló Z, Várnai P, Spät A. Angiotensin II inhibits potassium-induced calcium signal generation in rat adrenal glomerulosa cells. Biochem J (1991) 273:399-404. doi:10.1042/bj2730399

57. Cirillo M, Quinn SJ, Canessa ML. Early and late effects of angiotensin-II on $\mathrm{Ca}^{2+}$ fluxes in bovine adrenal zona glomerulosa cells. Endocrinology (1993) 132:1921-30. doi:10.1210/en.132.5.1921

58. Enyedi P, Mucsi I, Hunyady L, Catt KJ, Spät A. The role of guanyl nucleotide binding proteins in the formation of inositol phosphates in adrenal glomerulosa cells. Biochem Biophys Res Commun (1986) 140:941-7. doi:10.1016/0006-291X(86)90726-6

59. Enyeart JJ. Biochemical and Ionic signaling mechanisms for ACTHstimulated cortisol production. Vitam Horm (2005) 70:265-9. doi:10.1016/ S0083-6729(05)70008-X

60. Matthews EK, Saffran M. Ionic dependence of adrenal steroidogenesis and ACTH-induced changes in the membrane potential of adrenocortical cells. J Physiol (1973) 234:43-64. doi:10.1113/jphysiol.1973.sp010333

61. Lymangrover JR, Matthews EK, Saffran M. Membrane potential changes of mouse adrenal zona fasciculata cells in response to adrenocorticotropin and adenosine 3'5'-monophosphate. Endocrinology (1982) 110:462-8. doi:10.1210/endo-110-2-462

62. Enyeart JJ, Enyeart JA. Adrenal fasciculata cells express T-type and rapidly and slowly activating $\mathrm{L}$-type $\mathrm{Ca}^{2+}$ channels that regulate cortisol secretion. Am J Physiol Cell Physiol (2015) 308:C899-918. doi:10.1152/ajpcell.00002.2015

63. Enyeart JJ, Danthi SJ, Liu H, Enyeart JA. Angiotensin II inhibits bTREK-1 $\mathrm{K}^{+}$channels in adrenocortical cells by separate $\mathrm{Ca}^{2+}$ - and ATP hydrolysisdependent mechanisms. J Biol Chem (2005) 280:30814-28. doi:10.1074/jbc. M504283200

64. Enyeart JA, Danthi SJ, Enyeart JJ. TREK-1 $\mathrm{K}^{+}$channels couple angiotensin II receptors to membrane depolarization and aldosterone secretion in bovine adrenal glomerulosa cells. Am J Physiol Endocrinol Metab (2004) 287:E1154-65. doi:10.1152/ajpendo.00223.2004

65. Naville D, Lebrethon MC, Kermabon AY, Rouer E, Benarous R, Saez JM. Characterization and regulation of the angiotensin II type-1 receptor (binding and mRNA) in human adrenal fasciculata-reticularis cells. FEBS Lett (1993) 321:184-8. doi:10.1016/0014-5793(93)80104-3

66. Dell GC, Morley SD, Mullins JJ, Williams BC, Walker SW. Multiple signal transduction systems regulate angiotensin II type 1 (AT1) receptor mRNA expression in bovine adrenocortical cells. Endocr Res (1996) 22:363-8.

67. Bird IM, Magness RR, Mason JI, Rainey WE. Angiotensin-II acts via the type 1 receptor to inhibit 17 alpha-hydroxylase cytochrome P450 expression in ovine adrenocortical cells. Endocrinology (1992) 130:3113-21. doi:10.1210/ endo.130.6.1317775

68. Bird IM, Williams BC, Walker SW. Identification and metabolism of phosphoinositol species formed on angiotensin II stimulation of zona fasciculata-reticularis cells from the bovine adrenal cortex. Mol Cell Endocrinol (1992) 83:29-38. doi:10.1016/0303-7207(92)90192-9

69. Burnay MM, Vallotton MB, Capponi AM, Rossier MF. Angiotensin II potentiates adrenocorticotropic hormone-induced cAMP formation in bovine adrenal glomerulosa cells through a capacitative calcium influx. Biochem $J$ (1998) 330:21-7. doi:10.1042/bj3300021 
70. Trnka P, Orellana L, Walsh M, Pool L, Borzi P. Reninoma: an uncommon cause of Renin-mediated hypertension. Front Pediatr (2014) 2:89. doi:10.3389/ fped.2014.00089

71. Aguilar F, Lo M, Claustrat B, Saez JM, Sassard J, Li JY. Hypersensitivity of the adrenal cortex to trophic and secretory effects of angiotensin II in Lyon genetically-hypertensive rats. Hypertension (2004) 43:87-93. doi:10.1161/01. HYP.0000107194.44040.d4

72. Healy DP, Maciejewski AR, Printz MP. Autoradiographic localization of [125I]-angiotensin II binding sites in the rat adrenal gland. Endocrinology (1985) 116:1221-3. doi:10.1210/endo-116-3-1221

73. Lehoux JG, Bird IM, Briere N, Martel D, Ducharme L. Influence of dietary sodium restriction on angiotensin II receptors in rat adrenals. Endocrinology (1997) 138:5238-47. doi:10.1210/endo.138.12.5612

74. Whitley GSJ, Hyatt PJ, Tait JF. Angiotensin II-induced inositol phosphate production in isolated rat zona glomerulosa and fasciculata/reticularis cells. Steroids (1987) 49:271-86. doi:10.1016/0039-128X(87)90004-3

75. Braley LM, Menachery AI, Brown EM, Williams GH. Comparative effect of angiotensin II, potassium, adrenocorticotropin, and cyclic adenosine 3'5'-monophosphate on cytosolic calcium in rat adrenal cells. Endocrinology (1986) 119:1010-9. doi:10.1210/endo-119-3-1010

76. Parmar J, Key RE, Rainey WE. Development of an adrenocorticotropinresponsive human adrenocortical carcinoma cell line. JClin Endocrinol Metab (2008) 93:4542-6. doi:10.1210/jc.2008-0903

77. Rossier MF, Lesouhaitier O, Perrier E, Bockhorn L, Chiappe A, Lalevee N. Aldosterone regulation of T-type calcium channels. J Steroid Biochem $\mathrm{Mol}$ Biol (2003) 85:383-8. doi:10.1016/S0960-0760(03)00201-2

78. Szanda G, Koncz P, Várnai P, Spät A. Mitochondrial $\mathrm{Ca}^{2+}$ uptake with and without the formation of high- $\mathrm{Ca}^{2+}$ microdomains. Cell Calcium (2006) 40:527-38. doi:10.1016/j.ceca.2006.08.019

79. Kim YH, Park TJ, Lee YH, Baek KJ, Suh PG, Ryu SH, et al. Phospholipase C-deltal is activated by capacitative calcium entry that follows phospholipase C-beta activation upon bradykinin stimulation. J Biol Chem (1999) 274:26127-34. doi:10.1074/jbc.274.37.26127

80. Biden TJ, Altin JG, Karjalainen A, Bygrave FL. Stimulation of hepatic inositol 1,4,5-trisphosphate kinase activity by $\mathrm{Ca}^{2+}$-dependent and -independent mechanisms. Biochem J (1988) 256:697-701. doi:10.1042/bj2560697

81. Balla T, Baukal AJ, Guillemette G, Catt KJ. Multiple pathways of inositol polyphosphate metabolism in angiotensin-stimulated adrenal glomerulosa cells. J Biol Chem (1988) 263:4083-91.

82. Rossier MF, Dentand IA, Lew PD. Interconversion of inositol $(1,4,5)$-trisphosphate to inositol $(1,3,4,5)$-tetrakisphosphate and $(1,3,4)$-trisphosphate in permeabilized adrenal glomerulosa cells is calcium-sensitive and ATP-dependent. Biochem Biophys Res Commun (1986) 139:259-65. doi:10.1016/S0006-291X(86)80107-3

83. Spät A, Fabiato A, Rubin RP. Binding of inositol trisphosphate by a liver microsomal fraction. Biochem J (1986) 233:929-32. doi:10.1042/ bj2330929

84. Poirier SN, Poitras M, Chorvatova A, Payet MD, Guillemette G. FK506 blocks intracellular $\mathrm{Ca}^{2+}$ oscillations in bovine adrenal glomerulosa cells. Biochemistry (2001) 40:6486-92. doi:10.1021/bi010207k

85. Carafoli E. Calcium pump of the plasma membrane. Physiol Rev (1991) 71:129-53.

86. Netticadan T, Kato K, Tappia P, Elimban V, Dhalla NS. Phosphorylation of cardiac $\mathrm{Na}^{+}-\mathrm{K}^{+}$ATPase by $\mathrm{Ca}^{2+} /$ calmodulin dependent protein kinase. Biochem Biophys Res Commun (1997) 238:544-8. doi:10.1006/bbrc.1997.7305

87. Yingst DR, Davis J, Krenz S, Schiebinger RJ. Insights into the mechanism by which inhibition of Na,K-ATPase stimulates aldosterone production. Metabolism (1999) 48:1167-71. doi:10.1016/S0026-0495(99)90133-6

88. Hyatt PJ, Tait JF, Tait SAS. The mechanism of the effect of $\mathrm{K}^{+}$on the steroidogenesis of rat zona glomerulosa cells of the adrenal cortex: role of cyclic AMP. Proc R Soc Lond B Biol Sci (1986) 227:21-42. doi:10.1098/ rspb.1986.0007

89. Kojima I, Kojima K, Rasmussen H. Intracellular calcium and adenosine 3,5'-cyclic monophosphate as mediators of potassium-induced aldosterone secretion. Biochem J (1985) 228:69-76. doi:10.1042/bj2280069

90. Spät A. Stimulus-secretion coupling in angiotensin-stimulated adrenal glomerulosa cells. J Steroid Biochem (1988) 29:443-53. doi:10.1016/0022-4731(88)90256-7
91. Balla T, Hunyady L, Spät A. Possible role of calcium uptake and calmodulin in adrenal glomerulosa cells: effects of verapamil and trifluoperazine. Biochem Pharmacol (1982) 31:1267-71. doi:10.1016/0006-2952(82)90014-4

92. Kojima I, Kojima K, Rasmussen H. Role of calcium and cAMP in the action adrenocorticotropin on aldosterone secretion. J Biol Chem (1985) 260:4248-56.

93. Begeot M, Langlois D, Penhoat A, Saez JM. Variations in guanine-binding proteins (Gs, Gi) in cultured bovine adrenal cells. Consequences on the effects of phorbol ester and angiotensin II on adrenocorticotropin-induced and cholera-toxin-induced cAMP production. Eur JBiochem (1988) 174:317-21. doi:10.1111/j.1432-1033.1988.tb14100.x

94. Marie J, Jard S. Angiotensin II inhibits adenylate cyclase from adrenal cortex glomerulosa zone. FEBS Lett (1983) 159:97-101. doi:10.1016/0014-5793(83)80424-4

95. Hausdorff WP, Sekura RD, Aguilera G, Catt KJ. Control of aldosterone production by angiotensin II is mediated by two guanine nucleotide regulatory proteins. Endocrinology (1987) 120:1668-78. doi:10.1210/endo-120-4-1668

96. Bell JBG, Tait JF, Tait SAS, Barnes GD, Brown BL. Lack of effect of angiotensin on levels of cyclic AMP in isolated adrenal zona glomerulosa cells from the rat. J Endocrinol (1981) 91:145-54. doi:10.1677/joe.0.0910145

97. Woodcock EA, Johnston CI. Inhibition of adenylate cyclase in rat adrenal glomerulosa cells by angiotensin II. Endocrinology (1984) 115:337-41. doi:10.1210/endo-115-1-337

98. Katona D, Rajki A, Di BG, Pozzan T, Spät A. Calcium-dependent mitochondrial cAMP production enhances aldosterone secretion. Mol Cell Endocrinol (2015) 412:196-204. doi:10.1016/j.mce.2015.05.002

99. Coté M, Guillon G, Payet MD, Gallo-Payet N. Expression and regulation of adenylyl cyclase isoforms in the human adrenal gland. J Clin Endocrinol Metab (2001) 86:4495-503. doi:10.1210/jcem.86.9.7837

100. Cooper DM, Tabbasum VG. Adenylate cyclase-centred microdomains. Biochem J (2014) 462:199-213. doi:10.1042/BJ20140560

101. Nishimoto K, Rainey WE, Bollag WB, Seki T. Lessons from the gene expression pattern of the rat zona glomerulosa. Mol Cell Endocrinol (2013) 371:107-13. doi:10.1016/j.mce.2012.12.023

102. Shen T, Suzuki Y, Poyard M, Best-Belpomme M, Defer N, Hanoune J. Localization and differential expression of adenylyl cyclase messenger ribonucleic acids in rat adrenal gland determined by in situ hybridization. Endocrinology (1997) 138:4591-8. doi:10.1210/en.138.11.4591

103. Willoughby D, Cooper DM. Organization and $\mathrm{Ca}^{2+}$ regulation of adenylyl cyclases in cAMP microdomains. Physiol Rev (2007) 87:965-1010. doi:10.1152/physrev.00049.2006

104. Tremblay E, Payet MD, Gallo-Payet N. Effects of ACTH and angiotensin II on cytosolic calcium in cultured adrenal glomerulosa cells. Role of cAMP production in the ACTH effect. Cell Calcium (1991) 12:655-73. doi:10.1016/0143-4160(91)90036-E

105. Gallo-Payet N, Grazzini E, Coté M, Chouinard L, Chorvatova A, Bilodeau $\mathrm{L}$, et al. Role of $\mathrm{Ca}^{2+}$ in the action of adrenocorticotropin in cultured human adrenal glomerulosa cells. JClin Invest (1996) 98:460-6. doi:10.1172/ JCI118812

106. Fülöp L, Rajki A, Katona D, Szanda G, Spät A. Extramitochondrial OPA1 and adrenocortical function. Mol Cell Endocrinol (2013) 381:70-9. doi:10.1016/j. mce.2013.07.021

107. Durroux T, Gallo-Payet N, Payet MD. Effects of adrenocorticotropin on action potential and calcium currents in cultured rat and bovine glomerulosa cells. Endocrinology (1991) 129:2139-47. doi:10.1210/endo-129-4-2139

108. Lenglet S, Louiset E, Delarue C, Vaudry H, Contesse V. Activation of 5-HT(7) receptor in rat glomerulosa cells is associated with an increase in adenylyl cyclase activity and calcium influx through T-type calcium channels. Endocrinology (2002) 143:1748-60. doi:10.1210/endo.143.5.8817

109. Hunyady L, Balla T, Nagy K, Spät A. Control of phosphatidylinositol turnover in adrenal glomerulosa cells. Biochim Biophys Acta (1982) 713:352-7. doi:10.1016/0005-2760(82)90253-3

110. Hajnóczky G, Várnai P, Buday L, Faragó A, Spät A. The role of protein kinase-C in control of aldosterone production by rat adrenal glomerulosa cells: activation of protein kinase-C by stimulation with potassium. Endocrinology (1992) 130:2230-6. doi:10.1210/en.130.4.2230

111. Baukal AJ, Hunyady L, Balla T, Ely JA, Catt KJ. Modulation of agonist-induced inositol phosphate metabolism by cyclic adenosine 3',5'-monophosphate in 
adrenal glomerulosa cells. Mol Endocrinol (1990) 4:1712-9. doi:10.1210/ mend-4-11-1712

112. McCarthy RT, Isales CM, Bollag WB, Rasmussen H, Barrett PQ. Atrial natriuretic peptide differentially modulates T- and L-type calcium channels. Am J Physiol (1990) 258:F473-8.

113. Ganguly A. Atrial natriuretic peptide-induced inhibition of aldosterone secretion: a quest for mediator(s). Am J Physiol Endocrinol Metab (1992) 263:E181-94.

114. Coté M, Payet MD, Rousseau E, Guillon G, Gallo-Payet N. Comparative involvement of cyclic nucleotide phosphodiesterases and adenylyl cyclase on adrenocorticotropin-induced increase of cyclic adenosine monophosphate in rat and human glomerulosa cells. Endocrinology (1999) 140:3594-601. doi:10.1210/endo.140.8.6889

115. MacFarland RT, Zelus BD, Beavo JA. High concentrations of a cGMPstimulated phosphodiesterase mediate ANP-induced decreases in cAMP and steroidogenesis in adrenal glomerulosa cells. J Biol Chem (1991) 266:136-42.

116. Nikolaev VO, Gambaryan S, Engelhardt S, Walter U, Lohse MJ. Real-time monitoring of the PDE2 activity of live cells: hormone-stimulated cAMP hydrolysis is faster than hormone-stimulated cAMP synthesis. J Biol Chem (2005) 280:1716-9. doi:10.1074/jbc.C400505200

117. Vezzosi D, Bertherat J. Phosphodiesterases in endocrine physiology and disease. Eur J Endocrinol (2011) 165:177-88. doi:10.1530/EJE-10-1123

118. Fredlund P, Saltman S, Kondo T, Douglas J, Catt KJ. Aldosterone production by isolated glomerulosa cells: modulation of sensitivity to angiotensin II and ACTH by extracellular potassium concentration. Endocrinology (1977) 100:481-6. doi:10.1210/endo-100-2-481

119. Hajnóczky G, Várnai $P$, Holló Z, Christensen SB, Balla T, Enyedi $P$, et al. Thapsigargin-induced increase in cytoplasmic $\mathrm{Ca}^{2+}$ concentration and aldosterone production in rat adrenal glomerulosa cells: interaction with potassium and angiotensin-II. Endocrinology (1991) 128:2639-44. doi:10.1210/ endo-128-5-2639

120. Pratt JH, Rothrock JK, Dominguez JH. Evidence that angiotensin-II and potassium collaborate to increase cytosolic calcium and stimulate the secretion of aldosterone. Endocrinology (1989) 125:2463-9. doi:10.1210/ endo-125-5-2463

121. Spät A, Balla I, Balla T, Enyedi P, Hajnóczky G, Rohács T. Sustained stimulation of aldosterone production by angiotensin II is potentiated by nickel. Am J Physiol Endocrinol Metab (1990) 258:E555-61.

122. Dolmetsch RE, Pajvani U, Fife K, Spotts JM, Greenberg ME. Signaling to the nucleus by an L-type calcium channel-calmodulin complex through the MAP kinase pathway. Science (2001) 294:333-9. doi:10.1126/science.1063395

123. Kar P, Nelson C, Parekh AB. Selective activation of the transcription factor NFAT1 by calcium microdomains near $\mathrm{Ca}^{2+}$ release-activated $\mathrm{Ca}^{2+}$ (CRAC) channels. J Biol Chem (2011) 286:14795-803. doi:10.1074/jbc.M111.220582

124. Balla T, Szebeny M, Kanyár B, Spät A. Angiotensin II and FCCP mobilizes calcium from different intracellular pools in adrenal glomerulosa cells; analysis of calcium fluxes. Cell Calcium (1985) 6:327-42. doi:10.1016/0143-4160(85)90003-X

125. Balla T, Enyedi P, Hunyady L, Spät A. Effects of lithium on angiotensin-stimulated phosphatidylinositol turnover and aldosterone production in adrenal glomerulosa cells: a possible causal relationship. FEBS Lett (1984) 171:179-82. doi:10.1016/0014-5793(84)80483-4

126. Xing Y, Parker CR, Edwards M, Rainey WE. ACTH is a potent regulator of gene expression in human adrenal cells. J Mol Endocrinol (2010) 45:59-68. doi:10.1677/JME-10-0006

127. Nogueira EF, Xing Y, Morris CA, Rainey WE. Role of angiotensin II-induced rapid response genes in the regulation of enzymes needed for aldosterone synthesis. J Mol Endocrinol (2009) 42:319-30. doi:10.1677/JME-08-0112

128. Howard B, Wang Y, Xekouki P, Faucz FR, Jain M, Zhang L, et al. Integrated analysis of genome-wide methylation and gene expression shows epigenetic regulation of CYP11B2 in aldosteronomas. J Clin Endocrinol Metab (2014) 99:E536-43. doi:10.1210/jc.2013-3495

129. Pihlajoki M, Dorner J, Cochran RS, Heikinheimo M, Wilson DB. Adrenocortical zonation, renewal, and remodeling. Front Endocrinol (2015) 6:27. doi:10.3389/fendo.2015.00027

130. Drelon C, Berthon A, Mathieu M, Martinez A, Val P. Adrenal cortex tissue homeostasis and zonation: a WNT perspective. Mol Cell Endocrinol (2015) 408:156-64. doi:10.1016/j.mce.2014.12.014
131. Clyne CD, Zhang Y, Slutsker L, Mathis JM, White PC, Rainey WE. Angiotensin II and potassium regulate human CYP11B2 transcription through common cis-elements. Mol Endocrinol (1997) 11:638-49. doi:10.1210/mend.11.5.9920

132. Shanmughapriya S, Rajan S, Hoffman NE, Zhang X, Guo S, Kolesar JE, et al. $\mathrm{Ca}^{2+}$ signals regulate mitochondrial metabolism by stimulating CREBmediated expression of the mitochondrial $\mathrm{Ca}^{2+}$ uniporter gene MCU. Sci Signal (2015) 8:ra23. doi:10.1126/scisignal.2005673

133. Doi M, Satoh F, Maekawa T, Nakamura Y, Fustin JM, Tainaka M, et al. Isoform-specific monoclonal antibodies against 3beta-hydroxysteroid dehydrogenase/isomerase family provide markers for subclassification of human primary aldosteronism. J Clin Endocrinol Metab (2014) 99:E257-62. doi:10.1210/jc.2013-3279

134. Yarimizu D, Doi M, Ota T, Okamura H. Stimulus-selective induction of the orphan nuclear receptor NGFIB underlies different influences of angiotensin II and potassium on the human adrenal gland zona glomerulosa-specific 3beta-HSD isoform gene expression in adrenocortical H295R cells. Endocr J (2015) 62:765-76. doi:10.1507/endocrj.EJ15-0211

135. Bassett MH, Suzuki T, Sasano H, White PC, Rainey WE. The orphan nuclear receptors NURR1 and NGFIB regulate adrenal aldosterone production. Mol Endocrinol (2004) 18:279-90. doi:10.1210/me.2003-0005

136. Nogueira EF, Rainey WE. Regulation of aldosterone synthase by activator transcription factor/cAMP response element-binding protein family members. Endocrinology (2010) 151:1060-70. doi:10.1210/en.2009-0977

137. Szekeres M, Turu G, Orient A, Szalai B, Supeki K, Cserzo M, et al. Mechanisms of angiotensin II-mediated regulation of aldosterone synthase expression in H295R human adrenocortical and rat adrenal glomerulosa cells. Mol Cell Endocrinol (2009) 302:244-53. doi:10.1016/j.mce.2008.12.015

138. Wang X, Nickenig G, Murphy TJ. The vascular smooth muscle type I angiotensin II receptor mRNA is destabilized by cyclic AMP-elevating agents. Mol Pharmacol (1997) 52:781-7. doi:10.1124/mol.52.5.781

139. Wang X, Murphy TJ. Inhibition of cyclic AMP-dependent kinase by expression of a protein kinase inhibitor/enhanced green fluorescent fusion protein attenuates angiotensin II-induced type 1 AT1 receptor mRNA down-regulation in vascular smooth muscle cells. Mol Pharmacol (1998) 54:514-24.

140. Bird IM, Mason JI, Rainey WE. Hormonal regulation of angiotensin II type 1 receptor expression and AT1-RmRNA levels in human adrenocortical cells. Endocr Res (1995) 21:169-82. doi:10.3109/07435809509030432

141. McCormack JG, Halestrap AP, Denton RM. Role of calcium ions in regulation of mammalian intramitochondrial metabolism. Physiol Rev (1990) 70:391-425.

142. Pralong WF, Hunyady L, Várnai P, Wollheim CB, Spät A. Pyridine nucleotide redox state parallels production of aldosterone in potassium-stimulated adrenal glomerulosa cells. Proc Natl Acad Sci U S A (1992) 89:132-6. doi:10.1073/ pnas.89.1.132

143. Pralong WF, Spät A, Wollheim CB. Dynamic pacing of cell metabolism by intracellular $\mathrm{Ca}^{2+}$.J Biol Chem (1994) 269:27310-4.

144. Rohács T, Nagy G, Spät A. Cytoplasmic $\mathrm{Ca}^{2+}$ signalling and reduction of mitochondrial pyridine nucleotides in adrenal glomerulosa cells in response to $\mathrm{K}^{+}$, angiotensin II and vasopressin. Biochem J (1997) 322:785-92. doi:10.1042/bj3220785

145. Jouaville LS, Pinton P, Bastianutto C, Rutter GA, Rizzuto R. Regulation of mitochondrial ATP synthesis by calcium: evidence for a long-term metabolic priming. Proc Natl Acad Sci U S A (1999) 96:13807-12. doi:10.1073/ pnas.96.24.13807

146. Rizzuto R, Simpson AWM, Brini M, Pozzan T. Rapid changes of mitochondrial $\mathrm{Ca}^{2+}$ revealed by specifically targeted recombinant aequorin. Nature (1992) 358:325-7. doi:10.1038/358325a 0

147. Hajnóczky G, Robb-Gaspers LD, Seitz MB, Thomas AP. Decoding of cytosolic calcium oscillations in the mitochondria. Cell (1995) 82:415-24. doi:10.1016/0092-8674(95)90430-1

148. Brandenburger Y, Kennedy ED, Python CP, Rossier MF, Vallotton MB, Wollheim $\mathrm{CB}$, et al. Possible role for mitochondrial calcium in angiotensin II- and potassium-stimulated steroidogenesis in bovine adrenal glomerulosa cells. Endocrinology (1996) 137:5544-51. doi:10.1210/endo.137.12.8940382

149. Spät A, Pitter JG. The effect of cytoplasmic $\mathrm{Ca}^{2+}$ signal on the redox state of mitochondrial pyridine nucleotides. Mol Cell Endocrin (2004) 215:115-8. doi:10.1016/j.mce.2003.11.004 
150. Kamer KJ, Mootha VK. The molecular era of the mitochondrial calcium uniporter. Nat Rev Mol Cell Biol (2015) 16:545-53. doi:10.1038/ nrm4039

151. Rizzuto R, Brini M, Murgia M, Pozzan T. Microdomains with high $\mathrm{Ca}^{2+}$ close to $\mathrm{IP}_{3}$-sensitive channels that are sensed by neighboring mitochondria. Science (1993) 262:744-7. doi:10.1126/science.8235595

152. Pitter JG, Maechler P, Wollheim CB, Spät A. Mitochondria respond to $\mathrm{Ca}^{2+}$ already in the submicromolar range: correlation with redox state. Cell Calcium (2002) 31:97-104. doi:10.1054/ceca.2001.0264

153. Rohács T, Tory K, Dobos A, Spät A. Intracellular calcium release is more efficient than calcium influx in stimulating mitochondrial $\mathrm{NAD}(\mathrm{P}) \mathrm{H}$ formation in adrenal glomerulosa cells. Biochem J (1997) 328:525-8. doi:10.1042/ bj3280525

154. Wiederkehr A, Szanda G, Akhmedov D, Mataki C, Heizmann CW, Schoonjans $\mathrm{K}$, et al. Mitochondrial matrix calcium is an activating signal for hormone secretion. Cell Metab (2011) 13:601-11. doi:10.1016/j.cmet.2011.03.015

155. Spät A, Fülöp L, Szanda G. The role of mitochondrial $\mathrm{Ca}^{2+}$ and $\mathrm{NAD}(\mathrm{P})$ $\mathrm{H}$ in the control of aldosterone secretion. Cell Calcium (2012) 52:64-72. doi:10.1016/j.ceca.2012.01.009

156. Buck J, Sinclair ML, Schapal L, Cann MJ, Levin LR. Cytosolic adenylyl cyclase defines a unique signaling molecule in mammals. Proc Natl Acad Sci U S A (1999) 96:79-84. doi:10.1073/pnas.96.1.79

157. Chen Y, Cann MJ, Litvin TN, Iourgenko V, Sinclair ML, Levin LR, et al. Soluble adenylyl cyclase as an evolutionarily conserved bicarbonate sensor. Science (2000) 289:625-8. doi:10.1126/science.289.5479.625
158. Litvin TN, Kamenetsky M, Zarifyan A, Buck J, Levin LR. Kinetic properties of "soluble" adenylyl cyclase. Synergism between calcium and bicarbonate. J Biol Chem (2003) 278:15922-6. doi:10.1074/jbc.M212475200

159. Zippin JH, Chen Y, Nahirney P, Kamenetsky M, Wuttke MS, Fischman DA, et al. Compartmentalization of bicarbonate-sensitive adenylyl cyclase in distinct signaling microdomains. FASEB J (2003) 17:82-4.

160. Acin-Perez R, Salazar E, Kamenetsky M, Buck J, Levin LR, Manfredi G. Cyclic AMP produced inside mitochondria regulates oxidative phosphorylation. Cell Metab (2009) 9:265-76. doi:10.1016/j.cmet.2009.01.012

161. Di Benedetto G, Scalzotto E, Mongillo M, Pozzan T. Mitochondrial $\mathrm{Ca}^{2+}$ uptake induces cyclic AMP generation in the matrix and modulates organelle ATP levels. Cell Metab (2013) 17:965-75. doi:10.1016/j.cmet.2013.05.003

162. Berridge MJ. The interaction of cyclic nucleotides and calcium in the control of cell activity. Adv Cyclic Nucl Res (1975) 6:1-98.

Conflict of Interest Statement: The authors declare that the research was conducted in the absence of any commercial or financial relationships that could be construed as a potential conflict of interest.

Copyright (c) 2016 Spät, Hunyady and Szanda. This is an open-access article distributed under the terms of the Creative Commons Attribution License (CC BY). The use, distribution or reproduction in other forums is permitted, provided the original author(s) or licensor are credited and that the original publication in this journal is cited, in accordance with accepted academic practice. No use, distribution or reproduction is permitted which does not comply with these terms. 